\title{
Spontaneous Oscillations of Cytoplasmic Free Calcium Ion Concentration in Cultured Smooth Muscle Cells from Guinea Pig Ileum
}

\author{
Hisayuki Ohata', Toru Kawanishi², Megumi Kawanishi', Chikako Uneyama², \\ Michihito Takahashi ${ }^{2}$ and Kazutaka Momose ${ }^{1}$ \\ 'Department of Pharmacology, School of Pharmaceutical Sciences, Showa University, Shinagawa-ku, Tokyo 142, Japan \\ ${ }^{2}$ Division of Pathology, Biological Safety Research Center, National Institute of Health Sciences, Setagaya-ku, Tokyo 158, Japan
}

Received April 2, $1993 \quad$ Accepted June 16, 1993

\begin{abstract}
The cytoplasmic free calcium ion concentration $\left(\left[\mathrm{Ca}^{2+}\right]_{\mathrm{i}}\right)$ of cultured guinea pig ileum longitudinal muscle cells loaded with a fluorescent $\left[\mathrm{Ca}^{2+}\right]_{\mathrm{i}}$ indicator, fura-2, was measured by digital ratio imaging microscopy. Spontaneous $\left[\mathrm{Ca}^{2+}\right]_{i}$ oscillations were observed in $25 \%$ to $80 \%$ of the cells, which differed with the batches of the cultured cells after 5 to 8 days in culture. The frequency and amplitude of the $\left[\mathrm{Ca}^{2 \dagger}\right]_{i}$ oscillations in each individual cell were usually regular, but heterogeneity between neighboring cells was observed. The spontaneous $\left[\mathrm{Ca}^{2+}\right]_{i}$ oscillations were also observed even after incubation of the cells under a serum-free condition for $72 \mathrm{hr}$. Exchange of extracellular solution to $\mathrm{Ca}^{2+}$-free solution containing EGTA or BAPTA immediately stopped the $\left[\mathrm{Ca}^{2+}\right]_{i}$ oscillations. The ratio of the oscillating cells was dependent on the extracellular calcium ion concentration $\left(\left[\mathrm{Ca}^{2+}\right]_{0}\right)$; and heterogeneity in the range of the $\left[\mathrm{Ca}^{2+}\right]_{0}$ to generate the $\left[\mathrm{Ca}^{2+}\right]_{1}$ oscillations was observed. An inorganic $\mathrm{Ca}^{2+}$-antagonist, $\mathrm{LaCl}_{3}$, immediately suppressed the $\left[\mathrm{Ca}^{2+}\right]_{\mathrm{i}}$ oscillations, but the treatment with verapamil or nicardipine, $\mathrm{Ca}^{2+}$-channel blockers, did not have any effect on the $\left[\mathrm{Ca}^{2+}\right]_{\mathrm{i}}$ oscillations. An inhibitor of the intracellular $\mathrm{Ca}^{2+}$ pump, thapsigargin, induced a transient increase in $\left[\mathrm{Ca}^{2+}\right]_{\mathrm{i}}$ and then inhibited the spontaneous $\left[\mathrm{Ca}^{2+}\right]_{\mathrm{i}}$ oscillations. Neomycin, a compound known to inhibit phosphoinositide turnover, inhibited the $\left[\mathrm{Ca}^{2+}\right]_{\mathrm{i}}$ oscillations. These results suggest the following: (1) The generation of the spontaneous $\left[\mathrm{Ca}^{2+}\right]_{i}$ oscillations is highly dependent on $\left[\mathrm{Ca}^{2+}\right]_{0}$ but not due to $\mathrm{Ca}^{2+}$ influx through voltage-dependent $\mathrm{Ca}^{2+}$ channels; (2) Thapsigargin-sensitive $\mathrm{Ca}^{2+}$ pumping pools, which may be inositol 1,4,5-trisphosphate $\left(\mathrm{IP}_{3}\right)$-releasable $\mathrm{Ca}^{2+}$ pools, play an important role in generating the spontaneous $\left[\mathrm{Ca}^{2+}\right]_{\mathrm{i}}$ oscillations, and the uptake of $\mathrm{Ca}^{2+}$ into the pools is highly dependent on $\mathrm{Ca}^{2+}$ influx across the plasma membrane.
\end{abstract}

Keywords: Longitudinal muscle cell (cultured), Calcium oscillation, Thapsigargin

Changes in cytoplasmic free calcium ion concentration $\left(\left[\mathrm{Ca}^{2+}\right]_{\mathrm{i}}\right)$ are important for the regulation of many different cellular functions (1-3). Digital video imaging of fluorescence from intracellular indicators has allowed us to measure $\left[\mathrm{Ca}^{2+}\right]_{;}$in many cells simultaneously and resolve frequently oscillating changes of $\left[\mathrm{Ca}^{2+}\right]_{i}$ in each cell $(4,5)$. It has been suspected for a long time that $\left[\mathrm{Ca}^{2+}\right]_{\mathrm{j}}$ oscillations occur in electrically excitable cells. However, using this technique, $\left[\mathrm{Ca}^{2+}\right]_{\mathrm{i}}$ oscillations induced by hormones, growth factors, or neurotransmitters have been observed not only in excitable cells but also in nonexcitable cells $(6,7)$. In several cell types spontaneous $\left[\mathrm{Ca}^{2+}\right]_{\mathrm{i}}$ oscillations have also been observed $(8-10)$.

The $\left[\mathrm{Ca}^{2+}\right]_{\mathrm{i}}$ oscillations fall into two main categories, depending on whether they originate from the calcium influx (membrane oscillators) or from calcium release from internal stores (cytosolic oscillators) (6). Membrane oscillators depend on the opening and closing of voltagesensitive $\mathrm{Ca}^{2+}$ channels in the plasma membrane which are driven by membrane potential fluctuations. Cytosolic oscillators are frequently associated with stimuli that act through the phosphoinositide signaling pathway, and they probably reflect the complex feedback interactions responsible for regulating intracellular calcium. The cellular basis of the cytosolic oscillators is still unclear, although some models have been proposed $(6,11,12)$. At present, the $\left[\mathrm{Ca}^{2+}\right]_{i}$ oscillations in electrically excitable cells are considered to be mainly due to the membrane oscillators. On the other hand, in nonexcitable cells, cytosolic oscillators are thought to play main parts in the $\left[\mathrm{Ca}^{2+}\right]_{i}$ 
oscillations. However, phosphatidyl-inositol 4,5-bisphosphate breakdown to $\mathrm{IP}_{3}$ is presumed to oscillate along with $\left[\mathrm{Ca}^{2+}\right]_{\mathrm{i}}$ in some cell types, and an influx of external $\mathrm{Ca}^{2+}$ is also needed to maintain sustained $\left[\mathrm{Ca}^{2+}\right]_{\mathrm{i}}$ oscillations in many cell types $(6,12)$, suggesting that the mechanism of the $\left[\mathrm{Ca}^{2+}\right]$ oscillations differ depending on cell types.

In the present study, we cultured cells from ileum longitudinal muscle and measured the changes in $\left[\mathrm{Ca}^{2+}\right]_{i}$ by using a fluorescent $\left[\mathrm{Ca}^{2+}\right]_{i}$ indicator, fura-2. Spontaneous $\left[\mathrm{Ca}^{2+}\right]_{\mathrm{i}}$ oscillations were observed in the cells. The $\mathrm{Ca}^{2+}$ spike in spontaneous $\left[\mathrm{Ca}^{2+}\right]_{\mathrm{i}}$ oscillation was highly dependent on $\left[\mathrm{Ca}^{2+}\right]_{o}$, but not due to $\mathrm{Ca}^{2+}$ influx through voltage-dependent $\mathrm{Ca}^{2+}$ channels. In addition, thapsigarginsensitive and/or $\mathrm{IP}_{3}$-releasable intracellular $\mathrm{Ca}^{2+}$ pools seemed to contribute to generating the spontaneous $\left[\mathrm{Ca}^{2+}\right]_{\mathrm{i}}$ oscillations.

\section{MATERIALS AND METHODS}

\section{Materials}

Fura-2 acetoxymethyl ester (fura-2/AM) was obtained from Dojin Laboratories (Kumamoto). 1,2-Bis(2-amino5-fluorophenoxy) ethane- $N, N, N^{\prime}, N^{\prime}$-tetraacetic acid (BAPTA) was purchased from Molecular Probes (Eugene, OR, USA). Thapsigargin was obtained from Funakoshi (Tokyo). Verapamil, nicardipine and neomycin were from Sigma Chemical Co. (St. Louis, MO, USA). Caffeine and ryanodine were obtained from Wako Pure Chemicals (Osaka). Monoclonal antibody to smooth muscle cells was purchased from Boehringer Mannheim GmbH (Mannheim, Germany). Anti-myosin monoclonal antibody (clone 414/SB13) was from Sanbio bv (Uden, Netherlands). Fluorescence isothiocyanatelabeled antibody to mouse IgM was purchased from Kirkgaard \& Perry Laboratories, Inc. (Gaithersburg, MD, USA). All other chemicals were commercial products of the highest available grade of purity.

\section{Preparation of cultured longitudinal smooth muscle cell}

The small intestine was removed from male guinea pig $(200-400 \mathrm{~g})$, freed of fat and mesenteric tissue, and then the longitudinal smooth muscle was carefully stripped off and placed in Tyrode-Hepes solution composed of 137 $\mathrm{mM} \mathrm{NaCl}, 2.7 \mathrm{mM} \mathrm{KCl}, 1.8 \mathrm{mM} \mathrm{CaCl}_{2}, 1.0 \mathrm{mM} \mathrm{MgCl}_{2}$, $5.6 \mathrm{mM}$ glucose and $8.4 \mathrm{mM} \mathrm{N}$-2-hydroxyethylpiperazine- $N^{\prime}$-2-ethanesulfonic acid (Hepes), pH 7.4. The longitudinal muscle segments were cut into small pieces. Small explants of longitudinal muscle were cultured in minimum essential medium (MEM; Gibco, Gaithersburg, MD, USA) containing $20 \%$ fetal calf serum on 25 -mm-diameter glass coverslips inside 35 -mm Petri dishes and maintained at $37^{\circ} \mathrm{C}$ under humidified conditions of $95 \%$ air $-5 \% \mathrm{CO}_{2}$. After $24 \mathrm{hr}$, the culture medium was replaced with MEM containing 10\% fetal calf serum, and the medium was changed after 4 days in culture. Cells began to grow out from the explants after 4 days in culture. We confirmed that the cells after 7 days in culture were positively stained with monoclonal antibodies against myosin or smooth muscle cells and fluorescence isothiocyanate-labeled antibody to mouse IgM. The monoclonal antibody to smooth muscle cells recognizes smooth muscle cells of humans, pigs, mice, guinea pigs and rabbits, but does not react with endothelial cells, macrophages or fibroblasts. Therefore, we concluded that the cultured cells had originated from longitudinal muscle cells and used the cells after 5 to 8 days in culture for the experiments.

\section{Fura-2 loading of cells}

Fura-2 loading was started by adding $7.5 \mu \mathrm{l}$ of fura2/AM solution (1 $\mathrm{mM}$ in dimethylsulfoxide) to $3 \mathrm{ml}$ of the culture medium. Loading was carried out for $60 \mathrm{~min}$ at $37^{\circ} \mathrm{C}$ under $95 \%$ air $-5 \% \quad \mathrm{CO}_{2}$. After loading, the coverslips were rinsed several times with Tyrode-Hepes solution without the dye.

\section{Measurement of $\left[\mathrm{Ca}^{2+}\right]_{i}$}

After washing, the coverslips were mounted in an experimental chamber which fits upon the stage of a Nikon Diaphoto TMD inverted fluorescence microscope (Tokyo). Fura-2 fluorescence images were obtained at alternating excitation wavelengths of 350 and $385 \mathrm{~nm}$ through a 410$\mathrm{nm}$ dichroic reflector and BA492 IF filter, and collected by a Hamamatsu Photonics C2400-87 intensified CCD camera (Hamamatsu), and processed by a Hamamatsu Photonics ARGUS-50 image analyzer. The images collected for each wavelength of excitation ( 32 frames each) were averaged and corrected for background fluorescence. The $350 \mathrm{~nm} / 385 \mathrm{~nm}$ ratio was calculated on a pixel-by-pixel basis and converted to $\left[\mathrm{Ca}^{2+}\right]_{i}$ by using a calibration curve obtained with the same equipment using fura-2-containing ethylene glycol-bis( $\beta$-aminoethyl ether)$N, N, N^{\prime}, N^{\prime}$-tetraacetic acid (EGTA)-Ca ${ }^{2+}$ buffers $(0-$ $\left.1351 \mathrm{nM} \mathrm{Ca}{ }^{2+}\right)$. The mean $\left[\mathrm{Ca}^{2+}\right]_{i}$ for each individual cell was obtained by averaging the $\left[\mathrm{Ca}^{2+}\right]_{i}$ of each pixel within a rectanglar zone centered over the cell. The temperature was kept at $32^{\circ} \mathrm{C}$, since intracellular fluorescence of fura- 2 decreased rapidly at $37^{\circ} \mathrm{C}$, probably by dye leakage. The ratio images were taken every $12-13 \mathrm{sec}$, unless otherwise noted. Average data are expressed as the mean \pm S.E.

\section{RESULTS}

\section{Spontaneous $\left[\mathrm{Ca}^{2+}\right]_{i}$ oscillations}

Spontaneous $\left[\mathrm{Ca}^{2+}\right]_{\mathrm{i}}$ oscillations were observed in from 


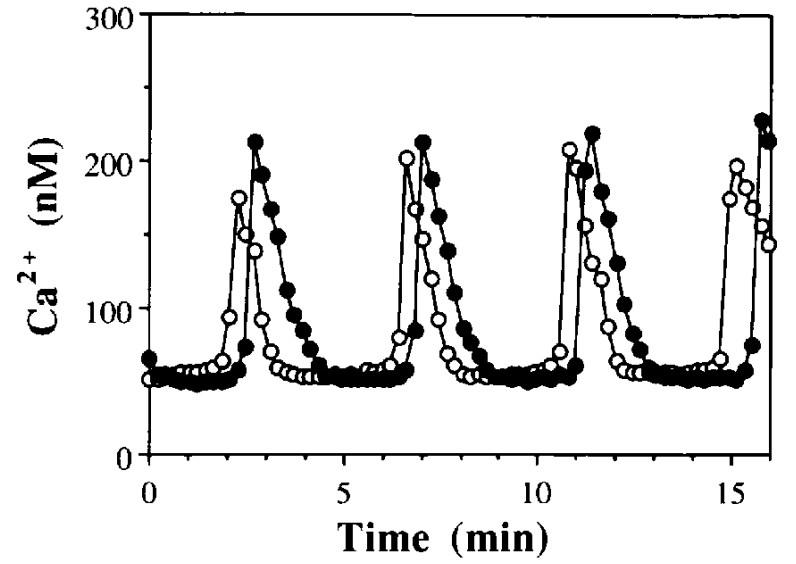

Fig. 1. Typical patterns of spontaneous $\left[\mathrm{Ca}^{2+}\right]_{i}$ oscillations in cultured longitudinal muscle cells of guinea pig ileum. Cells were loaded with fura-2, and the mean values of $\left[\mathrm{Ca}^{2+}\right]_{\mathrm{i}}$ in individual cells were measured as described in text. Closed and open circles represent two different cells in the same microscopic field.

$25 \%$ to $85 \%$ of the cultured longitudinal muscle cells from guinea pig ileum after 5 to 8 days in culture. The ratio of the oscillating cells differed with the batches of the cultured cells. The $\left[\mathrm{Ca}^{2+}\right]_{\mathrm{i}}$ oscillations were detected in cells in the center and peripheral regions of plaques, and they were not synchronous between contact cells. Figure 1 shows typical patterns of the spontaneous $\left[\mathrm{Ca}^{2+}\right]_{i}$ oscillations in the cells observed in one microscopic field. The frequency and amplitude of the $\left[\mathrm{Ca}^{2+}\right]_{i}$ oscillations in each individual cell were usually regular. The individual spikes showed a fast time-to-peak and a slow fall to the baseline levels. Heterogeneity in amplitude and frequency of $\left[\mathrm{Ca}^{2+}\right]_{i}$ oscillations between neighboring cells was observed. The baseline level of $\left[\mathrm{Ca}^{2+}\right]_{i}$ in the interspike was in the range of 40 to $180 \mathrm{nM}$ (mean $=65.3 \pm 4.1 \mathrm{nM}$, $\mathrm{n}=45)$, and the peak value of the $\left[\mathrm{Ca}^{2+}\right]_{i}$ spike was variable, reaching 100 to $400 \mathrm{nM}$ (mean $=178.9 \pm 9.7 \mathrm{nM}$, $n=45)$. The frequency of the $\left[\mathrm{Ca}^{2+}\right]_{i}$ oscillations was in the range of 0.15 to $0.40 / \mathrm{min}(0.304 \pm 0.019 / \mathrm{min}, \mathrm{n}=45)$. In these results, the temperature was kept at $32^{\circ} \mathrm{C}$, but the spontaneous $\left[\mathrm{Ca}^{2+}\right]_{i}$ oscillations were also observed at $37^{\circ} \mathrm{C}$ (data not shown). The cells showed no contratile response during the oscillatory increase in $\left[\mathrm{Ca}^{2+}\right]_{i}$, but they contracted at the higher levels of $\left[\mathrm{Ca}^{2+}\right]_{i}$ induced by the addition of $10 \mu \mathrm{M}$ ionomycin (data not shown).

After incubation of the cells under serum-free conditions for 24 or $48 \mathrm{hr},\left[\mathrm{Ca}^{2+}\right]_{\mathrm{i}}$ oscillations were observed (data not shown). Even after $72 \mathrm{hr},\left[\mathrm{Ca}^{2+}\right]_{\mathrm{i}}$ oscillations were still observed though the frequency and the amplitude were irregular (Fig. 2). The ratio of the oscillating cells under these conditions was in almost the same range (25 to $60 \%$ ) as that under the normal condition. The results suggest that $\left[\mathrm{Ca}^{2+}\right]_{i}$ oscillations are not generated

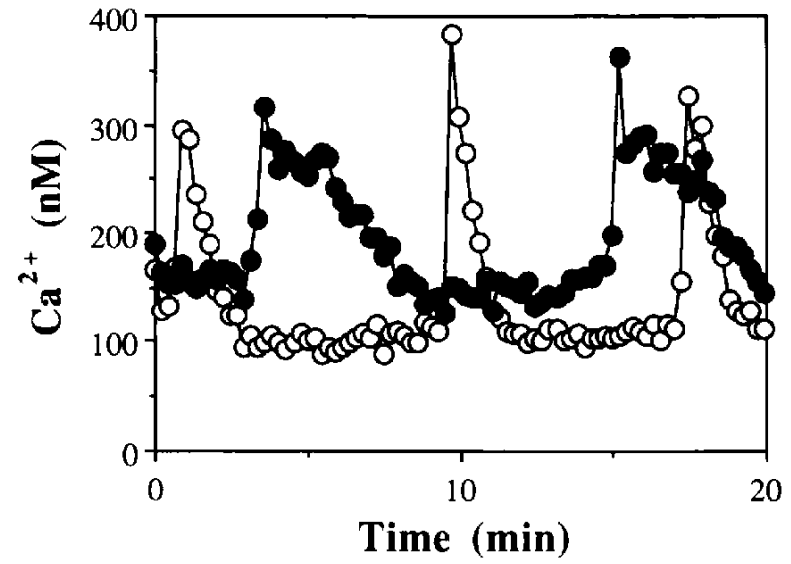

Fig. 2. Typical patterns of spontaneous $\left[\mathrm{Ca}^{2+}\right]_{\mathrm{i}}$ oscillations in cells after incubation under the serum-free condition. The culture medium was changed to serum-free MEM at the 5th day of culture; and after $72 \mathrm{hr}$, the $\left[\mathrm{Ca}^{2+}\right]_{\text {i }}$ was measured. Closed and open circles represent two different cells in the same microscopic field.
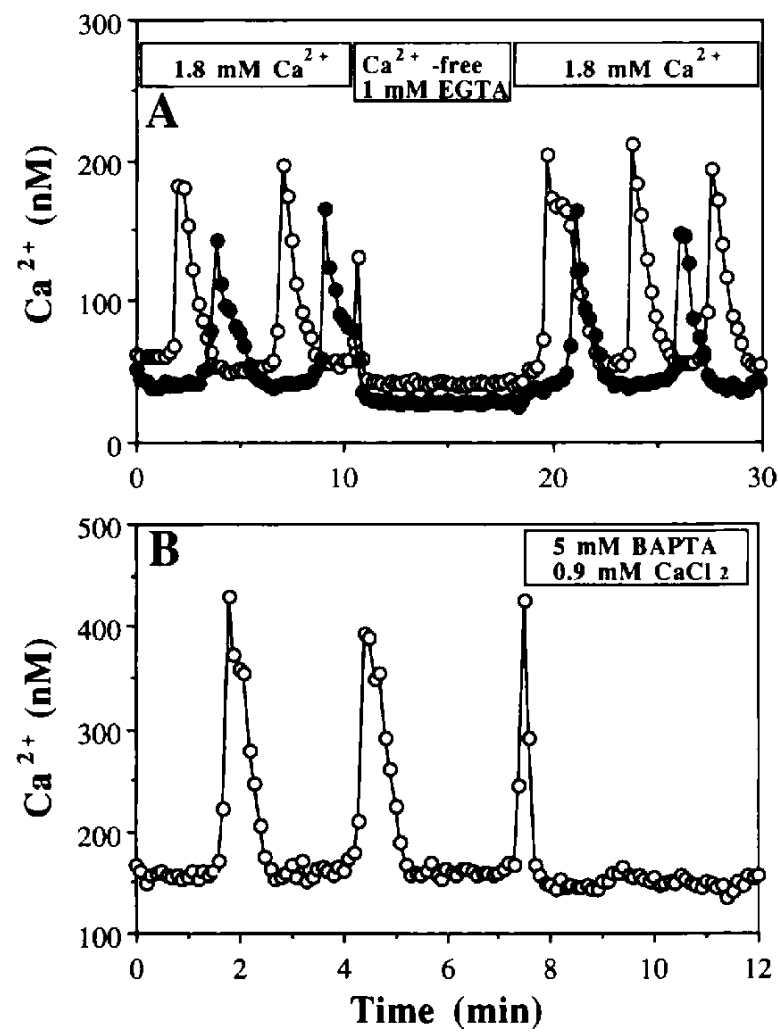

Fig. 3. Effect of reducing $\left[\mathrm{Ca}^{2+}\right]_{0}$ on spontaneous $\left[\mathrm{Ca}^{2+}\right]_{\mathrm{j}}$ oscillations. A: The $\left[\mathrm{Ca}^{2+}\right]_{i}$ in individual cells was measured in normal Tyrode-Hepes solution, and the medium was changed to $\mathrm{Ca}^{2+}$-free Tyrode-Hepes solution containing $1 \mathrm{mM}$ EGTA as shown at the top of the panel. Then, normal Tyrode-Hepes solution was restored. Open (cell 1) and closed (cell 2) circles represent two different cells in the same microscopic field. $\mathrm{B}:\left[\mathrm{Ca}^{2+}\right]_{\mathrm{i}}$ in the cell was measured in 1.5 $\mathrm{ml}$ of normal Tyrode-Hepes solution, and then $1.5 \mathrm{ml}$ of $\mathrm{Ca}^{2+}-$ free Tyrode-Hepes solution containing $10 \mathrm{mM}$ BAPTA was added to the normal Tyrode-Hepes solution as shown at the top of the panel. Ratio images were taken every $6 \mathrm{sec}$. 
at least by the short time effects of growth factors or hormones contained in fetal calf serum.

\section{Effect of $\left[\mathrm{Ca}^{2+}\right]_{0}$ on spontaneous $\left[\mathrm{Ca}^{2+}\right]_{i}$ oscillations}

Figure 3A shows the effect of removing extracellular $\mathrm{Ca}^{2+}$ on the spontaneous $\left[\mathrm{Ca}^{2+}\right]_{i}$ oscillations. Exchange of Tyrode-Hepes solution to $\mathrm{Ca}^{2+}$-free Tyrode-Hepes solution containing $1 \mathrm{mM}$ EGTA inhibited the $\left[\mathrm{Ca}^{2+}\right]_{\mathrm{i}}$ oscillations in all the cells, and the resultant baseline levels of $\left[\mathrm{Ca}^{2+}\right]_{\mathrm{i}}$ were slightly lower than the normal level. In particular, as shown in cell 1 in Fig. 3A, the spontaneous increase in $\left[\mathrm{Ca}^{2+}\right]_{\mathrm{i}}$ immediately declined before reaching to the peak of the $\left[\mathrm{Ca}^{2+}\right]_{i}$ spike by an exchange to the $\mathrm{Ca}^{2+}$. free solution and returned to the baseline level within 12 $\mathrm{sec}$, although the width of the spike in this cell was more than $90 \mathrm{sec}$ in normal solution. Restoration to normal $\left[\mathrm{Ca}^{2+}\right]_{o}$ started the $\left[\mathrm{Ca}^{2+}\right]_{\mathrm{i}}$ oscillations again at the normal frequency and amplitude in most cells. As there was a possibility that spatialy changing $\mathrm{pH}$ near the plasma membranes by adding EGTA stopped the oscillation, we also used BAPTA to reduce $\left[\mathrm{Ca}^{2+}\right]_{0}$ without changing the $\mathrm{pH}$ (Fig. 3B). An addition of the same volume of $\mathrm{Ca}^{2+}$ free Tyrode-Hepes solution containing $10 \mathrm{mM}$ BAPTA, which reduces $\left[\mathrm{Ca}^{2+}\right]_{0}$ to about $20 \mathrm{nM}$, also dumped the $\left[\mathrm{Ca}^{2+}\right]_{\mathrm{i}}$ oscillations. These results indicate that the generation of the spontaneous $\left[\mathrm{Ca}^{2+}\right]_{i}$ oscillations is highly dependent on the presence of extracellular calcium. Figure 4 shows the effect of $\left[\mathrm{Ca}^{2+}\right]_{0}$ on the spontaneous $\left[\mathrm{Ca}^{2+}\right]_{\mathrm{i}}$ oscillations of four different cells in one microscopic field. The $\left[\mathrm{Ca}^{2+}\right]_{i}$ oscillations were stopped by an exchange of normal Tyrode-Hepes solution to $\mathrm{Ca}^{2+}$-free TyrodeHepes solution in all oscillating cells. Then, with a step increase in $\left[\mathrm{Ca}^{2+}\right]_{o}$, the spontaneous $\left[\mathrm{Ca}^{2+}\right]_{\mathrm{i}}$ oscillations began again, although the range of the $\left[\mathrm{Ca}^{2+}\right]_{0}$ to generate the $\left[\mathrm{Ca}^{2+}\right]_{i}$ oscillations was also dependent on the cells. The regenerating $\left[\mathrm{Ca}^{2 \dagger}\right]_{\mathrm{j}}$ oscillations were stopped again in the higher plateau level of $\left[\mathrm{Ca}^{2+}\right]_{\mathrm{i}}$ by readditions of 3.6 $\mathrm{mM} \mathrm{Ca}^{2+}$ (Fig. 4A) and $1.8 \mathrm{mM} \mathrm{Ca}^{2+}$ (Fig. 4B) in $14.7 \%$ and $23.5 \%$ of 34 cells in one microscopic field, respectively. On the other hand, in $8.8 \%$ of the cells, the $\left[\mathrm{Ca}^{2+}\right]_{i}$ oscillations were generated by addition of more than 3.6 $\mathrm{mM} \mathrm{Ca}^{2+}$ to the cells (Fig. 4D).

Role of $\mathrm{Ca}^{2+}$ entry across the plasma membrane in the spontaneous $\left[\mathrm{Ca}^{2+}\right]_{i}$ oscillations

Figure 5A shows the effect of $\mathrm{LaCl}_{3}$, an inorganic $\mathrm{Ca}^{2+}$
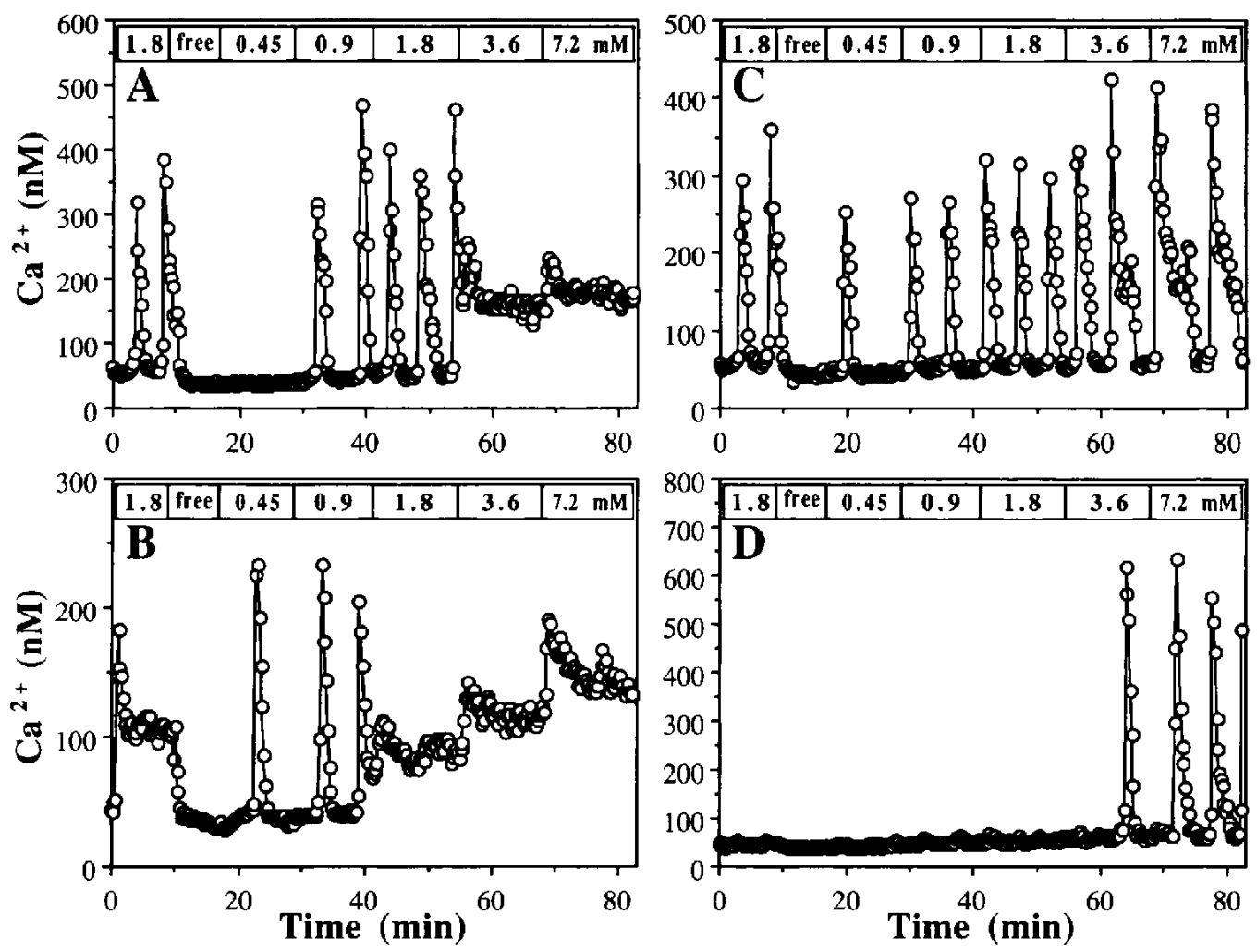

Fig. 4. Effect of $\left[\mathrm{Ca}^{2+}\right]_{0}$ on spontaneous $\left[\mathrm{Ca}^{2+}\right]_{i}$ oscillations. The $\left[\mathrm{Ca}^{2+}\right]_{\mathrm{i}}$ in individual cells was measured in normal TyrodeHepes solution; and then the medium was changed to $\mathrm{Ca}^{2+}$-free Tyrode-Hepes solution (free), followed by readdition of $\mathrm{Ca}^{2+}$ at increasing concentrations as shown at the top of the panel. The numbers in the top of the panel represent $\left[\mathrm{Ca}^{2+}\right]_{0}(\mathrm{mM})$. Each panel $(A-D)$ represents four different cells in the same microscopic field. 

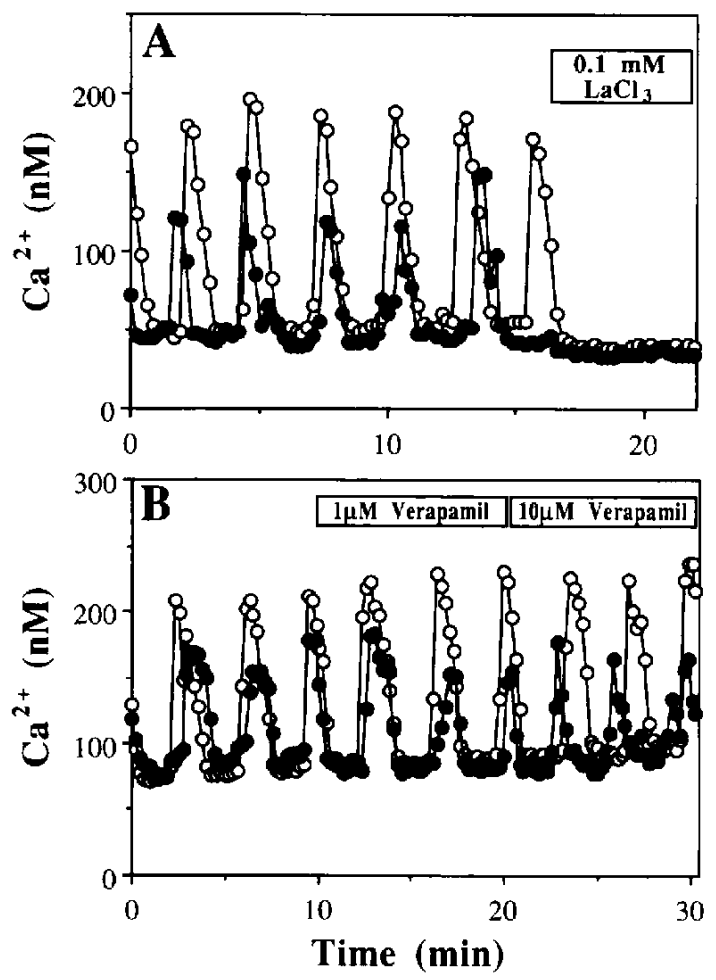

Fig. 5. Effects of $\mathrm{LaCl}_{3}$ and verapamil on spontaneous $\left[\mathrm{Ca}^{2+}\right]_{\mathrm{i}}$ oscillations. The $\left[\mathrm{Ca}^{2+}\right]_{i}$ in individual cells was measured in normal Tyrode-Hepes solution, and then $0.1 \mathrm{mM} \mathrm{LaCl}_{3}$ (A) and $10 \mu \mathrm{M}$ verapamil (B) were added to the cells as shown at the top of the panel. Closed and open circles represent two different cells in the same microscopic field.

antagonist, on the spontaneous $\left[\mathrm{Ca}^{2+}\right]_{i}$ oscillations. Addition of $0.1 \mathrm{mM} \mathrm{LaCl}_{3}$ to the cultured cells immediately abolished the $\left[\mathrm{Ca}^{2+}\right]_{i}$ oscillations in all cells, where the resultant baseline levels of $\left[\mathrm{Ca}^{2+}\right]_{i}$ were slightly lower than the normal baseline levels. These results show that the spontaneous $\left[\mathrm{Ca}^{2+}\right]_{i}$ oscillations are closely related with $\mathrm{Ca}^{2+}$ entry across the plasma membrane. We then examined whether the $\left[\mathrm{Ca}^{2+}\right]_{i}$ oscillations were due to $\mathrm{Ca}^{2+}$ influx through voltage-dependent $\mathrm{Ca}^{2+}$ channels by using $\mathrm{Ca}^{2+}$-channel blockers. Addition of 1 and $10 \mu \mathrm{M}$ verapamil, a blocker of L-type voltage-dependent $\mathrm{Ca}^{2+}$-channels, to the cultured cells did not have any effect on the $\left[\mathrm{Ca}^{2+}\right]_{\mathrm{i}}$ oscillations as shown in Fig. 5B. Treatment with $10 \mu \mathrm{M}$ nicardipine, a blocker of L-type voltage-dependent $\mathrm{Ca}^{2+}$-channels, also did not have any effect on them (data not shown).

We also examined the effect of membrane depolarization by isotonic $100 \mathrm{mM} \mathrm{KCl}$ on the $\left[\mathrm{Ca}^{2+}\right]_{\mathrm{i}}$ oscillations (Fig. 6A). Isotonic substitution of $100 \mathrm{mM} \mathrm{KCl}$ for $\mathrm{NaCl}$ in Tyrode-Hepes solution induced a transient increase in $\left[\mathrm{Ca}^{2+}\right]_{i}$ and then increased the frequency of the $\left[\mathrm{Ca}^{2+}\right]_{i}$ oscillations in less than $10 \%$ of the cells. However, in more than $90 \%$ of the cells, the substitution did not increase the
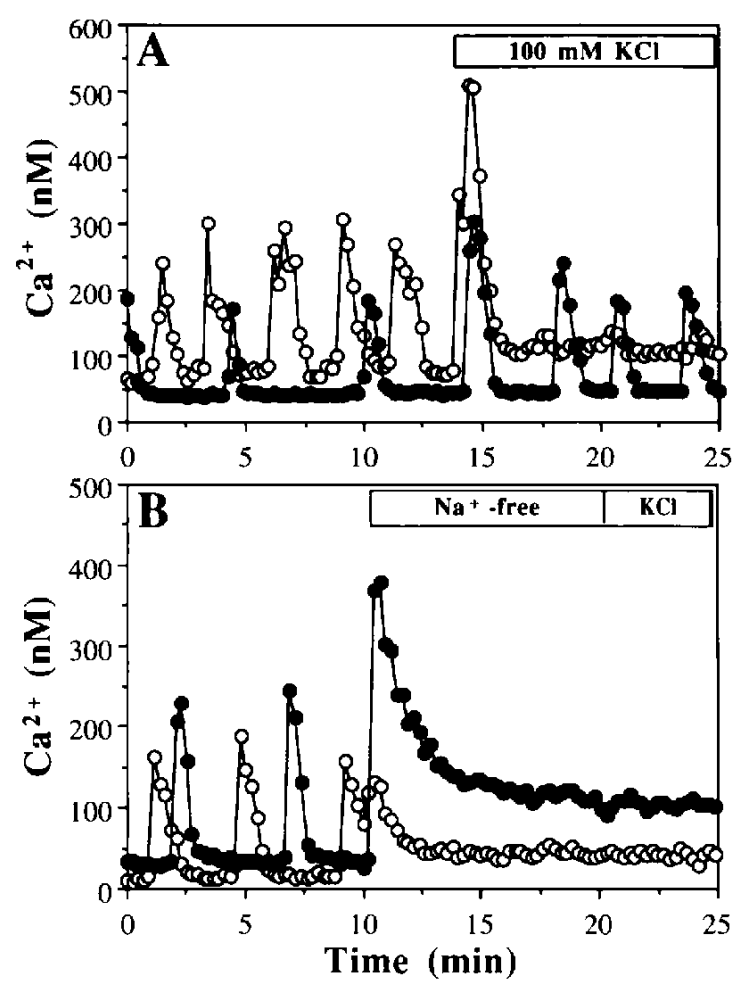

Fig. 6. Effects of isotonic $100 \mathrm{mM} \mathrm{KCl}$ and choline-substituted $\mathrm{Na}^{+}$-free solution on spontaneous $\left[\mathrm{Ca}^{2+}\right]_{i}$ oscillations. A: The $\left[\mathrm{Ca}^{2+}\right]_{\mathrm{i}}$ in individual cells was measured in normal Tyrode-Hepes solution, and then the medium was changed to isotonic $100 \mathrm{mM} \mathrm{KCl}$ TyrodeHepes solution as shown at the top of the panel. Closed and open circles represent two different cells in the same microscopic field. B: The medium was changed to choline-substituted $\mathrm{Na}^{-}$-free TyrodeHepes solution ( $\mathrm{Na}^{+}$-free), and then the medium was changed to isotonic $100 \mathrm{mM} \mathrm{KCl}$ Tyrode-Hepes solution $(\mathrm{KCl})$ as shown at the top of the panel. Closed and open circles represent two different cells in the same microscopic field.

frequency and amplitude of the $\left[\mathrm{Ca}^{2+}\right]_{i}$ oscillations. In more than half of the cells, the frequency of the $\left[\mathrm{Ca}^{2+}\right]_{i}$ oscillations was rather decreased. Furthermore, we also found that the choline-substituted $\mathrm{Na}^{+}$-free solution had the same effects on the $\left[\mathrm{Ca}^{2+}\right]_{\mathrm{i}}$ oscillations (Fig. $6 \mathrm{~B}$ ), suggesting that the effect of $\mathrm{KCl}$-substitution is not due to the membrane depolarization but also the decrease of $\mathrm{Na}^{\text {- }}$ $\mathrm{Ca}^{2+}$ exchange resulting from the decrease of the gradient of $\mathrm{Na}^{+}$concentration between the cytoplasm and the extracellular solution.

\section{Role of intracellular $\mathrm{Ca}^{2+}$ pools in the spontaneous $\left[\mathrm{Ca}^{2+}\right]_{i}$ oscillations}

We examined whether the function of intracellular $\mathrm{Ca}^{2+}$ pools is associated with the spontaneous $\left[\mathrm{Ca}^{2+}\right]_{\mathrm{i}}$ oscillations by using thapsigargin, an inhibitor of the endoplasmic reticulum $\mathrm{Ca}^{2+}$-ATPase pump $(13,14)$. Figure 7A shows the effect of thapsigargin on the spontaneous $\left[\mathrm{Ca}^{2+}\right]_{\mathrm{i}}$ oscillations. Addition of $0.5 \mu \mathrm{M}$ thapsigargin to 

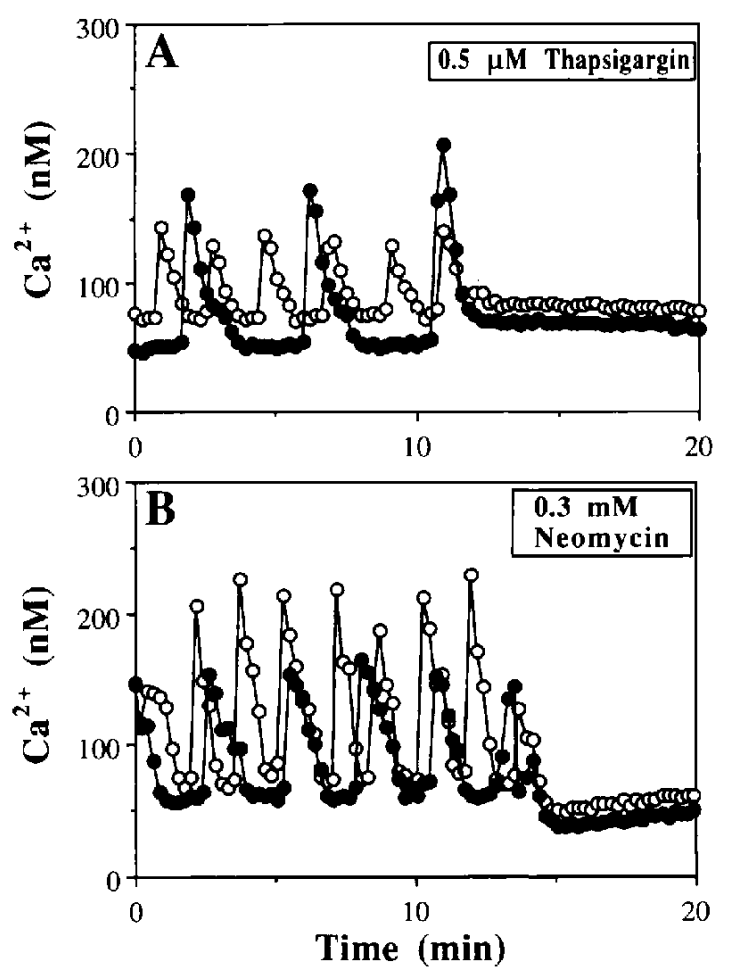

Fig. 7. Effects of thapsigargin and neomycin on spontaneous $\left[\mathrm{Ca}^{2+}\right]_{\mathrm{i}}$ oscillations. The $\left[\mathrm{Ca}^{2+}\right]_{i}$ in individual cells was measured in normal Tyrode-Hepes solution, and then $0.5 \mu \mathrm{M}$ thapsigargin (A) and $0.3 \mathrm{mM}$ neomycin (B) were added to the cells as shown at the top of the panel. Closed and open circles represent two different cells in the same microscopic field.

the cultured cells induced a transient increase in $\left[\mathrm{Ca}^{2+}\right]_{\mathrm{i}}$ and then inhibited the $\left[\mathrm{Ca}^{2+}\right]_{\mathrm{i}}$ oscillations in all cells. The resultant steady levels of $\left[\mathrm{Ca}^{2+}\right]_{i}$ after the transient increase in $\left[\mathrm{Ca}^{2+}\right]_{\mathrm{j}}$ by thapsigargin were slightly higher than the normal baseline levels but the increase was only less than $30 \mathrm{nM}$. In cells without spontaneous $\left[\mathrm{Ca}^{2+}\right]_{\mathrm{i}}$ oscillations, thapsigargin also caused a transient increase in $\left[\mathrm{Ca}^{2+}\right]_{\mathrm{i}}$ (data not shown). These results suggest that thapsigargin-sensitive $\mathrm{Ca}^{2+}$ pumping pools play an important role in generating the spontaneous $\left[\mathrm{Ca}^{2+}\right]_{\mathrm{i}}$ oscillations.

Thapsigargin is considered to empty the intracellular calcium pool released by $\mathrm{IP}_{3}(15)$, although it also seemed to empty the other intracellular calcium pool (16). We therefore investigated the effects of neomycin, a compound known to inhibit phosphoinositide turnover (17). As shown in Fig. 7B, $0.3 \mathrm{mM}$ neomycin inhibited the $\left[\mathrm{Ca}^{2+}\right]_{\mathrm{i}}$ oscillations in all cells.

We next determined whether the mechanism of $\mathrm{Ca}^{2+}$-induced $\mathrm{Ca}^{2+}$ release from the intracellular $\mathrm{Ca}^{2+}$ pools is related to the spontaneous $\left[\mathrm{Ca}^{2+}\right]_{\mathrm{i}}$ oscillations by using caffeine $(18,19)$ and ryanodine $(20,21)$, modulators of $\mathrm{Ca}^{2+}$-induced $\mathrm{Ca}^{2+}$ release. Addition of $10 \mathrm{mM}$ caffeine to the cultured cells decreased the frequency of the oscilla-
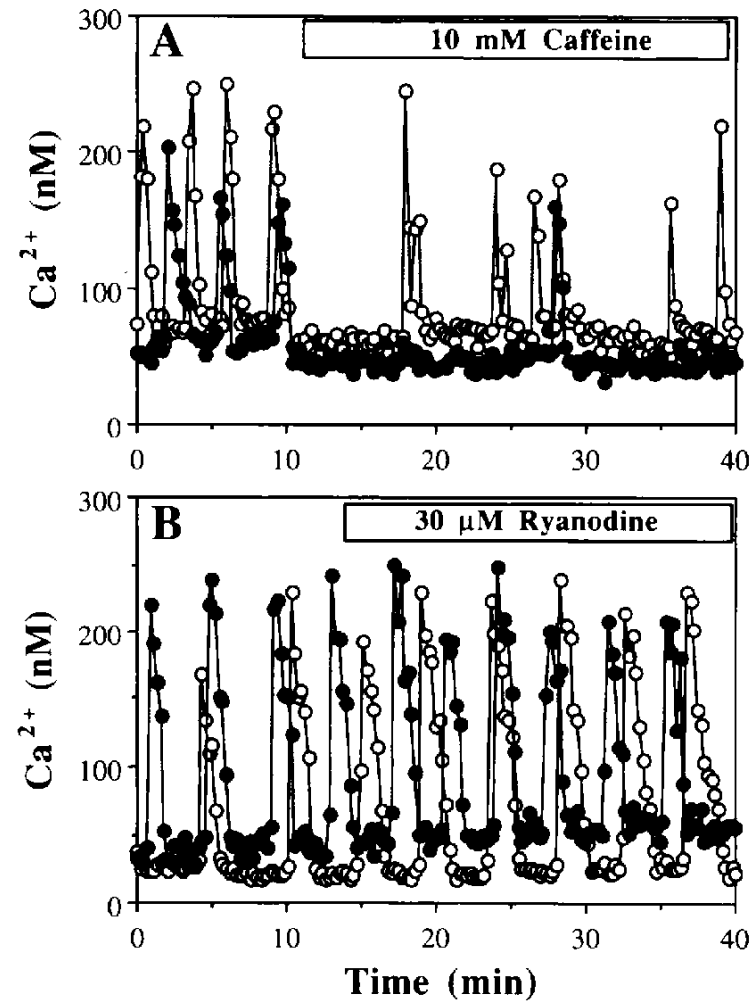

Fig. 8. Effect of caffeine and ryanodine on spontaneous $\left[\mathrm{Ca}^{2+}\right]_{i}$ oscillations. The $\left[\mathrm{Ca}^{2+}\right]_{i}$ in individual cells was measured in normal Tyrode-Hepes solution, and $10 \mathrm{mM}$ caffeine (A) and $30 \mu \mathrm{M}$ ryanodine $(B)$ were added to the cells as shown at the top of the panel. Closed and open circles represent two different cells in the same microscopic field.

tions without any increase in $\left[\mathrm{Ca}^{2+}\right]_{i}$ as shown in Fig. 8A. The same effect was also observed by the addition of 5 $\mathrm{mM}$ caffeine (data not shown). Treatment with $30 \mu \mathrm{M}$ ryanodine did not have any significant effect on the $\left[\mathrm{Ca}^{2+}\right]_{i}$ oscillations in most cells even at $25 \mathrm{~min}$ after the addition to the cultured cells as shown in Fig. 8B.

\section{DISCUSSION}

In the present study, we found spontaneous $\left[\mathrm{Ca}^{2+}\right]_{i}$ oscillations in a considerable fraction of the cultured longitudinal muscle cells from guinea pig ileum. Because all cells did not show the $\left[\mathrm{Ca}^{2+}\right]_{i}$ oscillations, there was a possibility that more than two kinds of cells were contained in our preparations. Recently Publicover et al. (9) reported that interstitial cells obtained from canine colon showed spontaneous $\left[\mathrm{Ca}^{2+}\right]_{\mathrm{i}}$ oscillations. However, the morphology of the interstitial cells is much different from that of the cultured longitudinal muscle cells. In addition, the oscillation of the interstitial cells was inhibited by nicardipine (9), unlike the cultured cells in the present study. Nearly all of the cultured cells showed positive 
labeling with monoclonal antibodies against smooth muscle cells or myosin, indicating that the cultured cells originate from longitudinal muscle cells, but not fibroblasts or endothelial cells. Furthermore, since the ratio of oscillating cells was dependent on $\left[\mathrm{Ca}^{2+}\right]_{0}$ as shown in Fig. 4, the difference between oscillating and nonoscillating cells might be due to the heterogeneity in the range of $\left[\mathrm{Ca}^{2+}\right]_{0}$ necessary to generate the $\left[\mathrm{Ca}^{2+}\right]_{i}$ oscillations, but not due to the existence of multiple populations of cells in our preparations. The $\left[\mathrm{Ca}^{2+}\right]_{i}$ oscillations were not synchronous between neighboring cells, suggesting that the generation of the $\left[\mathrm{Ca}^{2+}\right]_{i}$ oscillations was regulated in each individual cell, and the $\left[\mathrm{Ca}^{2+}\right]_{i}$ oscillation in a cell does not spread to neighboring cells, unlike $\left[\mathrm{Ca}^{2+}\right]_{\mathrm{i}}$ oscillations in cultured endothelial cell monolayers (22).

The spontaneous $\left[\mathrm{Ca}^{2+}\right]_{i}$ oscillations were inhibited immediately after the decrease in $\left[\mathrm{Ca}^{2+}\right]_{\mathrm{o}}$ and then began again after readdition of $\mathrm{CaCl}_{2}$. The $\left[\mathrm{Ca}^{2+}\right]_{1}$ oscillations were also inhibited by $\mathrm{LaCl}_{3}$. These results suggest that the influx of an appropriate amount of $\mathrm{Ca}^{2+}$ across the plasma membrane is needed to generate the $\left[\mathrm{Ca}^{2+}\right]_{i}$ oscillations. However, each $\mathrm{Ca}^{2+}$ spike in the spontaneous oscillations did not seem to be caused by $\mathrm{Ca}^{2+}$ influx through the voltage-dependent $\mathrm{Ca}^{2+}$ channel, since neither verapamil nor nicardipine affected the spontaneous $\left[\mathrm{Ca}^{2+}\right]_{i}$ oscillations. $\mathrm{La}^{3+}$ displaces membrane-bounded $\mathrm{Ca}^{2+}$ and therefore inhibits not only voltage-dependent $\mathrm{Ca}^{2+}$ channels, but also most membrane-transport processes involving $\mathrm{Ca}^{2+}(23)$. Therefore, the spontaneous $\left[\mathrm{Ca}^{2+}\right]_{1}$ Oscillations may be closely related to $\mathrm{Ca}^{2+}$ entry through the pathway inhibited by $\mathrm{LaCl}_{3}$, but not by verapamil or nicardipine. These properties of the spontaneous $\left[\mathrm{Ca}^{2+}\right]_{i}$ oscillations in the cultured longitudinal muscle cells were different from those in some excitable cells. For example, in cultured interstitial cells from canine colon (9), nicardipine at concentrations known to block the voltage-dependent $\mathrm{Ca}^{2+}$ channel in these cells blocked spontaneous $\left[\mathrm{Ca}^{2+}\right]_{\mathrm{j}}$ oscillations, suggesting that spontaneous electrical events generated by the cells are the source of the $\left[\mathrm{Ca}^{2+}\right]_{\mathrm{i}}$ oscillations. In addition, from the results that the effect of $\mathrm{K}^{+}$-depolarization on the oscillations was almost the same as that of the choline-substitution of $\mathrm{Na}^{+}$, there is a possibility that voltage-dependent $\mathrm{Ca}^{2+}$ channels did not function sufficiently in the growing longitudinal muscle cells as well as in the cultured vascular smooth muscle cells (24).

In many cell types, thapsigargin inhibits agonist-induced $\mathrm{Ca}^{2+}$ responses; and this effect is explained by the depletion of $\mathrm{Ca}^{2+}$ in the intracellular stores following the inhibition of $\mathrm{Ca}^{2+}$-ATPase $(15,22)$. On the other hand, in rat parotid acinar cells, the depletion of $\mathrm{Ca}^{2-}$ from the $\mathrm{IP}_{3}$-sensitive pool by thapsigargin enhances plasma membrane $\mathrm{Ca}^{2+}$ permeability and triggers sustained $\left[\mathrm{Ca}^{2 \vdash}\right]_{\mathrm{i}}$ os- cillations (25). In the present study, thapsigargin inhibited the spontaneous $\left[\mathrm{Ca}^{2+}\right]_{\mathrm{i}}$ oscillations in the cultured longitudinal muscle cells. Thapsigargin induced a $\left[\mathrm{Ca}^{2+}\right]_{i}$ transient followed by a plateau that is slightly higher than the normal baseline levels. Therefore, there was a possibility that the increase in the baseline level of $\left[\mathrm{Ca}^{2+}\right]_{\mathrm{i}}$ suppressed the $\left[\mathrm{Ca}^{2+}\right]_{i}$ oscillations by disrupting the feedback mechanism in the oscillations. However, the increase was only less than $30 \mathrm{nM}$. Thus the other possibility that the spontaneous $\left[\mathrm{Ca}^{2+}\right]_{\mathrm{i}}$ oscillations were suppressed by the depletion of $\mathrm{Ca}^{2+}$ from intracellular $\mathrm{Ca}^{2+}$ pools that contain a thapsigargin-sensitive $\mathrm{Ca}^{2+}$ pump is thought to be more reasonable. At present, we can not conclude whether the thapsigargin-sensitive $\mathrm{Ca}^{2+}$ pumping pools which play an important role in generating the $\left[\mathrm{Ca}^{2+}\right]_{\mathrm{i}}$ oscillations is the same as the $\mathrm{IP}_{3}$-sensitive $\mathrm{Ca}^{2+}$ stores, but the inhibitory effect of neomycin on the generation of the spontaneous $\left[\mathrm{Ca}^{2+}\right]_{i}$ oscillations support the involvement of the $\mathrm{IP}_{3}$-sensitive $\mathrm{Ca}^{2+}$ pools in the mechanism of the spontaneous $\left[\mathrm{Ca}^{2+}\right]_{\mathrm{i}}$ oscillations.

Berridge and Galione (6) have proposed the second messenger-controlled model of $\mathrm{Ca}^{2+}$ oscillations based on the existence of two releasable pools of calcium, which are the $\mathrm{IP}_{3}$-releasable pools and $\mathrm{Ca}^{2+}$-releasable pools. To investigate the participation of $\mathrm{Ca}^{2+}$-releasable pools on the mechanism of the spontaneous $\left[\mathrm{Ca}^{2+}\right]_{i}$ oscillations, we also examined the effects of caffeine and ryanodine, known modulators of $\mathrm{Ca}^{2+}$-induced $\mathrm{Ca}^{2+}$ release. It has been demonstrated that spontaneous $\left[\mathrm{Ca}^{2+}\right]_{\mathrm{i}}$ fluctuation in rat chromaffin cells arise from $\mathrm{Ca}^{2+}$-induced $\mathrm{Ca}^{2+}$ release from the results that caffeine increased the fluctuation frequency or induced a rapid $\left[\mathrm{Ca}^{2+}\right]_{i}$ transient followed by a plateau and ryanodine induced a progressive increase of the fluctuation duration followed by a high noisy plateau (26). In the present study, caffeine inhibited the spontaneous $\left[\mathrm{Ca}^{2+}\right]_{i}$ oscillations, but did not induce any transient increase in $\left[\mathrm{Ca}^{2+}\right]_{i}$, suggesting the release of $\mathrm{Ca}^{2+}$ from the store sites. Ryanodine did not have any effect on the $\left[\mathrm{Ca}^{2+}\right]_{\mathrm{i}}$ oscillations. These effects are different from those in rat chromaffin cells (26). The results suggested that typical $\mathrm{Ca}^{2+}$-induced $\mathrm{Ca}^{2+}$ release mechanisms (18) were not related to the spontaneous $\left[\mathrm{Ca}^{2+}\right]_{i}$ oscillations in the cultured longitudinal muscle cells, although at present, we can not deny the possibility that the properties of the $\mathrm{Ca}^{2+}$-induced $\mathrm{Ca}^{2+}$ release mechanisms are changed during the culturing of the cells. Further studies are required to elucidate the mechanisms of $\mathrm{Ca}^{2+}$ release from intracellular pools in the spontaneous $\left[\mathrm{Ca}^{2+}\right]_{\mathrm{i}}$ oscillations.

From the above discussion, it is concluded that $\mathrm{Ca}^{2+}$ release from the intracellular $\mathrm{Ca}^{2+}$ pools is responsible for the spontaneous $\left[\mathrm{Ca}^{2+}\right]_{i}$ oscillations. However, we also found that the generation of the oscillations was highly de- 
pendent on the presence of extracellular $\mathrm{Ca}^{2+}$. The results suggest that the large part of the $\mathrm{Ca}^{2+}$, which is taken up into the intracellular $\mathrm{Ca}^{2+}$ pools again after each $\mathrm{Ca}^{2-}$ spike in the $\left[\mathrm{Ca}^{2+}\right]_{i}$ oscillations, is coming from outside of the cells through any mechanism such as the conformational coupling model proposed by Berridge $(11,27)$.

What is the physiological role of the spontaneous $\left[\mathrm{Ca}^{2+}\right]_{\mathrm{i}}$ oscillation? There is a possibility that the oscillations are related to the spontaneous rhythms of electrical and mechanical activity in ileal smooth muscle. Based on the period duration and time course of the different components of spontaneous activity, smooth muscle rhythms were classified as follows: spikes, second-rhythm, minuterhythm and hour-rhythm (28). In guinea pig taenia coli, verapamil decreased the frequency of the spike discharges and second-rhythm in electrical and mechanical activity, but the frequency of minute-rhythm remained almost unchanged (29). Therefore, the spontaneous $\left[\mathrm{Ca}^{2+}\right]_{i}$ oscillations observed in the cultured longitudinal muscle cells might be related to the minute-rhythm reported in the visceral smooth muscle, although the contractile response in the cultured cells could not be observed during the spontaneous $\left[\mathrm{Ca}^{2+}\right]_{i}$ oscillations. At present, we can not deny the possibility that the $\left[\mathrm{Ca}^{2+}\right]_{i}$ oscillations were properties of only cultured smooth muscle cells, but we want to emphasize the fact that the cultured cells were proliferating as shown in the experiments where the uptake of bromo-deoxyuridine into the nuclei of the cells was measured (unpublished observation). Recently, Kojima et al. (30) reported that in primed competent BALB/c3T3 cells, oscillations of $\left[\mathrm{Ca}^{2+}\right]_{\mathrm{i}}$ was induced by the stimulation of insulin-like growth factor I, followed by meiosis. In addition, it has been suggested that emptying of $\mathrm{Ca}^{2+}$ from the intracellular thapsigargin-sensitive $\mathrm{Ca}^{2+}$-pumping pools induced profound alteration of cell proliferation (31). Therefore, the spontaneous $\left[\mathrm{Ca}^{2-}\right]_{\mathrm{i}}$ oscillations found in the present investigation may be also related to cell growth. Further studies are required to elucidate what the function of the spontaneous $\left[\mathrm{Ca}^{2+}\right]_{j}$ oscillations is in the cultured longitudinal muscle cells.

\section{REFERENCES}

1 Campbell, A.K.: Intracellular Calcium. John Wiley \& Sons, New York (1983)

2 Rusmussen, H. and Barrett, P.Q.: Calcium messenger system: an integrated view. Physiol. Rev. 64, 938-984 (1984)

3 Carafoli, E.: Intracellular calcium homeostasis. Annu. Rev. Biochem. 56, 395-433 (1987)

4 Grynkiewicz, G., Poenie, M. and Tsien, R.Y.: A new generation of $\mathrm{Ca}^{2+}$ indicators with greatly improved fluorescence properties. J. Biol. Chem. 260, 3440-3450 (1985)

5 Tsien, R.Y. and Poenie, M.: Fluorescence ratio imaging: a new window into intracellular ionic signaling. Trends Biochem. Sci.
11, 450-455 (1986)

6 Berridge, M.J. and Galione, A.: Cytosolic calcium oscillators. FASEB J, 2, 3074-3082 (1988)

7 Jacob, R.: Calcium oscillations in electrically non-excitable cells. Biochim. Biophys. Acta 1052, 427-438 (1990)

8 Schlegel, W., Winiger, B.P., Mollard, P., Vacher, P., Wuarin, F., Zahnd, G.R., Wollheim, C.B. and Dufy, B.: Oscillations of cytosolic $\mathrm{Ca}^{2+}$ in pituitary cells due to action potentials. Nature 329, 719-721 (1987)

9 Publicover, N.G., Horowitz, N.N. and Sanders, K.M.: Calcium oscillations in freshly dispersed and cultured interstitial cells from canine colon. Am. J. Physiol. 262, C589-C597 (1992)

10 Mayer, E.A., Kodner, A., Sun, X.P., Wilkes, J., Scott, D. and Sachs, G.: Spatial and temporal patterns of intracellular calcium in colonic smooth muscle. J. Membr. Biol. 125, 107-118 (1992)

11 Berridge, M.J.: Calcium oscillations. J. Biol. Chem. 265, 9583-9586 (1990)

12 Tsien, R.W. and Tsien, R.Y.: Calcium channels, stores, and oscillations. Annu. Rev. Cell Biol. 6, 715-760 (1990)

13 Thastrup, O., Dawson, A.P., Scharff, O., Foder, B., Cullen, P.J., Drøbak, B.K., Bjerrum, P.J., Christensen, S.B. and Hanley, M.R.: Thapsigargin, a novel molecular probe for studying intracellular calcium release and storage. Agents Actions 27, 17-23 (1989)

14 Thastrup, O., Cullen, P.J., Drøbak, B.K., Hanley, M.R. and Dawson, A.P.: Thapsigargin, a tumor promoter, discharges intracellular $\mathrm{Ca}^{2+}$ stores by specific inhibition of the endoplasmic reticulum $\mathrm{Ca}^{2+}$-ATPase. Proc. Natl. Acad. Sci. U.S.A. 87, 2466-2470 (1990)

15 Jackson, T.R., Patterson, S.I., Thastrup, O. and Hanley, M.R.: A novel tumour promoter, thapsigargin, transiently increases cytoplasmic free $\mathrm{Ca}^{2+}$ without generation of inositol phosphates in NG115-401L neuronal cells. Biochem. J. 253, $81-86$ (1988)

16 Bian, J., Ghosh, T.K., Wang, J.C. and Gill, D.L.: Identification of intracellular calcium pools. Selective modification by thapsigargin. J. Biol. Chem. 266, 8801-8806 (1991)

17 Williams, S.E. and Schacht, J.: Binding of neomycin and calcium to phospholipids and other anionic compounds. J. Antibiot. 39, 457-462 (1986)

18 Endo, M.: Calcium release from the sarcoplasmic reticulum. Physiol. Rev, 57, 71-108 (1977)

19 Martonosi, A.N.: Mechanisms of $\mathrm{Ca}^{2+}$ release from sarcoplasmic reticulum of skeletal muscle. Physiol. Rev. 64, 1240-1320 (1984)

20 Iino, M., Kobayashi, T. and Endo, M.: Use of ryanodine for functional removal of the calcium store in smooth muscle cells of the guinea-pig. Biochem. Biophys. Res. Commun. 152, $417-422$ (1988)

21 Iino, M.: Biphasic $\mathrm{Ca}^{2+}$ dependence of inositol 1,4,5-triphosphate-induced $\mathrm{Ca}$ release in smooth muscle cells of the guinea pig taenia caeci. J. Gen. Physiol. 95, 1103-1122 (1990)

22 Laskey, R.E., Adams, D. J., Cannell, M. and van Breemen, C.: Calcium entry-dependent oscillations of cytoplasmic calcium concentration in cultured endothelial cell monolayers. Proc. Natl. Acad. Sci. U.S.A. 89, 1690-1694 (1992)

23 dos Remedios, C.G.: Lanthanide ion probes of calcium-binding sites on cellular membranes. Cell Calcium 2, 29-51 (1981)

24 Masuo, M., Toyooka, T., Shin, W.S. and Sugimoto, T.: 
Growth-dependent alterations of intracellular $\mathrm{Ca}^{2+}$-handling mechanisms of vascular smooth muscle cells. PDGF negatively regulated functional expression of voltage-dependent, $\mathrm{IP}_{3^{-}}$ mediated, and $\mathrm{Ca}^{2+}$-induced $\mathrm{Ca}^{2+}$ release channels. Circ. Res. 69, $1327-1339$ (1991)

25 Foskett, J.K., Roifman, C.M. and Wong, D.: Activation of calcium oscillations by thapsigargin in parotid acinar cells. I. Biol. Chem. 266, 2778-2782 (1991)

26 Malgaroli, A., Fersce, R. and Meldolesi, J.: Spontaneous $\left[\mathrm{Ca}^{2+}\right]_{\mathrm{i}}$ fluctuations in rat chromaffin cells do not require inositol 1,4,5-trisphosphate elevations but are generated by a caffeine- and ryanodine-sensitive intracellular $\mathrm{Ca}^{2+}$ store. $\mathrm{J}$. Biol. Chem. 265, 3005-3008 (1990)

27 Berridge, M.J.: Inositol triphosphate and calcium signalling. Nature 361, 315-325 (1993)
28 Golenhofen, K. and Loh, D.: Intracellulär Potentialmessungen zur normalen Spontanaktivität der isolierten Portalvene des Meerschweinchens. Pflugers Arch. 319, 82-100 (1970) (Abs. in English)

29 Golenhofen, K. and Lammel, E.: Selective suppression of some components of spontaneous activity in various types of smooth muscle by iproveratril (verapamil). Pflugers Arch. 331, 233243 (1972)

30 Kojima, I., Mogami, H. and Ogata, E.: Oscillation of cytoplasmic free calcium concentration induced by insulin-like growth factor I. Am. J. Physiol. 262, E307-E311 (1992)

31 Ghosh, T.K., Bian, J., Short, A.D., Rybak, S.L. and Gill, D.L.: Persistent intracellular calcium pool depletion by thapsigargin and its influence on cell growth. J. Biol. Chem. 266, 24690-24697 (1991) 